\title{
Development of Softskill Training Models to Increase Personal and Social Competencies of Educators Prospective
}

\author{
Kartika Hajati, Dede Rahmat Hidayat, Muhammad Aswad
}

Faculty of Teacher Traning and Education, Universitas Sulawesi Barat, West Sulawesi Indonesia Email: kartikajamil@unsulbar.ac.id, aswad@unsulbar.ac.id

\begin{abstract}
This study aims to develop a soft skill development model for educators prospective. As a person who is an example and an example for students, every LPTK student must have high personal and social competencies. As it is known that there are 4 competencies that must be possessed by the teacher, namely professional competence, pedagogical competence, personal competence and social competence. For the first two competencies (professional and pedagogical) the curriculum in the LPTK already has a content that supports the two competencies. Soft skill is an important component in education that is still ignored. Cognitive and conative abilities in the education domain are categorized as hard skills, while other abilities related to social skills and the ability to have self awareness are categorized as soft skills. The research method used is Research Development which is carried out in 2 stages. Stage I as the first year is (a) Mapping soft skills that are owned by students and their implications for the patterns of relationships they develop (b) Develop learning models that can improve soft skills. Phase II conducted in the second year was to implement the model in several schools to determine the effectiveness and efficiency of the model by using mixed methods, namely quantitative methodology with explanatory research design model and qualitative method with exploratory research design model. In the first stage, the product research is a soft skill instrument and data on the level of soft skills of prospective educators at UNJ. Based on the research process carried out, obtained softskill instruments that have good instrument character, the instrument test is carried out in the first two stages through the assessment of experts (expert judgment) by two experts, the first psychologist and the two instrument experts. Furthermore, empirical tests were conducted for students at UNJ, the results obtained were that the instrument items had validity ranging from 0.197 to 0.660 . Reliability testing with Cronbach's alpha also has a high value, which is 0.728. Furthermore, mapping of soft skills for FIP students, obtained an illustration that the mean
\end{abstract}

value is self awareness 2.8 , self skills 2.8, interpersonal skills 3.2 and social skills 2.9.

Keywords- Soft skills, measurement, soft skill development models.

\section{INTRODUCTION}

The aim of education in Indonesia is to build the Indonesian people as a whole (building his soulto build his body), there is an emphasis on aspects of the soul (can be translated mentally). This condition makes it possible to continue to be developed and actualized through education. Chapter II, Article 3 of Law No. 20 of 2003 concerning the National Education System states that the aim of national education is "To develop the potential of students to become faithful and fearful people of God Almighty, noble, healthy, knowledgeable, capable, creative, independent and become citizens who democratic and responsible."

Education in Indonesia is not only to facilitate students to achieve high intellectual intelligence, but also has good emotional and spiritual intelligence. These three dimensions are important to be achieved in an integrated manner, taught holistically in order to reach the complete Indonesian people. Education is expected to be a bridge for the progress of the nation, because one of the main pillars in achieving progress is superior human quality.

Educators as part of the implementing component of the learning process are required to have abilities / competencies that are appropriate to the learning objectives. Government Regulation No. 19 of 2005, concerning the National Education Standards requires the existence of pedagogic competencies, professional competencies, personality competencies and social competencies that must be possessed by every educator at every level of education, so as to guarantee the implementation of an optimal learning process (Directorate of PTK-PNF, 2005).

The advantages possessed in education make it possible to bring the nation to a high level in the realm of global life, which is characterized by the ability to communicate 
equally and mastery of adequate science and technology.

However, it must be admitted that the advancement of science and technology has brought humans to the world that is not limited (borderless), the world shrinks into so small, so that everyone can relate to each other without distance. Indonesia in the global constellation is expected to be a nation that has an advanced level of education because this is the key to becoming a civilized and dignified nation.

Indonesia strives to be on the path of progress, various achievements have been shown (economic, technological, sports and arts progress). In various scientific events Indonesian students achieved good performance (many champions of physics, biology, computers, robotics, etc.). Although it must also be realized there are still many various shortcomings and problems that surround: poverty, social conflict (horizontal and vertical), dependence on other nations, corruption and various abuse of power and authority, violence on various scales.

The education developed needs to have a balanced orientation between cognitive, psychomotor and affective abilities and religiosity. Various directions of government policies regarding education issues begin to focus on improving mental abilities (affection) such as character education, life skills, reflecting the anxiety of educational orientation. For its operationalization a comprehensive and integrative curriculum development is needed to improve students' soft skills, education which refers to 5 pillars of education (learning to know, learning to do, learning, learning to learn and learning to live together).

In research conducted by researchers regarding the handling of problematic students through play therapy, which was funded by fundamental grants in 2013, it was concluded that students who were problematic were caused by the low ability to deal with the problem and the absence of a companion to overcome the problem. old and teacher as educators at school.

Softskill is seen as an important element in education at the tertiary level (Adam, 2012). The main purpose of life skills education is to prepare students to have the skills, abilities and skills needed to maintain their survival and develop themselves, so as to be able to overcome various problems in daily life.

\section{METHOD}

This research is a multi-year study. The research method used is research and development, because it is carried out through several continuous stages. The chosen research method is research and development. Development research is directed as "a process used to develop and validate educational products" (Borg and Gall: 2003). The intended product is a Soft Skill Development model for prospective educators. According to Borg and Gall (2003), the steps taken in development research include: (1) preliminary study, (2) planning, (3) development of a hypotheticalmodel, (4) review of hypothetical models, (5) revisions, (6) limited trials, (7) revision of trial results, (8) wider trials, (9) final model revisions, and ( 10) dissemination and socialization.

This development activity is a continuous work cycle activity, with the same steps. The results of the evaluation will return to the second step, namely development and so on (Sams pson et.al: 2004).

\section{DISCUSSION}

In the first year, there are two research results that will be presented, firstly the results of the development of soft skill test instruments and secondly the measurement results regarding the soft skills of prospective educators.

1. Results of the development of soft-skills instruments for prospective educators

The instrument developed is an instrument to measure the soft skills of prospective educators. There are 3 main components of skills which consist of internal skills (Intrapersonal skills), Interpersonal skills and social skills . The purpose of developing this instrument is to map out the important skills that must be possessed by the teacher, in the hope that the existence of these skills can be known, or the types of skills that have not been or are already owned by prospective educators, the complete instrument grid is as follows:

Table.1: Instrument Grid of Educator's Prospective

\begin{tabular}{|c|c|c|c|c|c|c|}
\hline No & Aspect & & Indicator & & Subindicator & No \\
\hline \multirow[t]{4}{*}{1} & \multirow[t]{4}{*}{ Intrapersonal Skill } & \multirow[t]{3}{*}{1} & \multirow[t]{3}{*}{ Self Awareness } & 1 & Self Confident & $1,2,3$ \\
\hline & & & & 2 & Self Assessment & $4,5,6$ \\
\hline & & & & 3 & Emotional Awareness & $7,8,9,10$ \\
\hline & & \multirow[t]{6}{*}{2} & \multirow[t]{6}{*}{ Self Skill } & 4 & Self Improvement & $\begin{array}{l}11,12,13,14, \\
15\end{array}$ \\
\hline & & & & 5 & Self Control & $16,17,18$ \\
\hline & & & & 6 & Trust Worthiness & $19,20,21$ \\
\hline & & & & 7 & Time/Source Management & $22,23,24$ \\
\hline & & & & 8 & Proaktif & $25,26,27$ \\
\hline & & & & 9 & Conscience & $28,29,30$ \\
\hline
\end{tabular}




\begin{tabular}{|c|c|c|c|c|c|c|}
\hline \multirow[t]{5}{*}{2} & \multirow[t]{5}{*}{ Interpersonal Skill } & \multirow[t]{5}{*}{3} & \multirow[t]{5}{*}{ Social Awareness } & 10 & Political Awareness & 31,32 \\
\hline & & & & 11 & Developing Others & $33,34,35$ \\
\hline & & & & 12 & Leveraging Diversity & $36,37,38$ \\
\hline & & & & 13 & Service Orientation & $39,40,41$ \\
\hline & & & & 14 & Honestly & $42,43,44$ \\
\hline \multirow[t]{6}{*}{3} & \multirow[t]{6}{*}{ Social Skill } & \multirow[t]{6}{*}{4} & \multirow[t]{6}{*}{ Leadership } & 15 & Unfluence & $45,46,47$ \\
\hline & & & & 16 & Communication Skills & $48,49,50$ \\
\hline & & & & 17 & Conflict Management & $51,52,53$ \\
\hline & & & & 18 & Team Work & $54,55,56$ \\
\hline & & & & 19 & Team Work & $57,58,59$ \\
\hline & & & & 20 & Sinergi & $60,61,62$ \\
\hline
\end{tabular}

In this study, the steps taken in developing soft skills for prospective educators are: 1) analyzing the goals and objectives to be achieved; 2) compile a map of the main concepts based on goals and objectives; 3) compile a blueprint for the test design; 4) sorting out concept maps based on indicators that want to be developed into test items; 5) compile specifications for one or more items; 6) writing questions based on the specifications of the items that have been developed; and determine scoring rubrics or guidelines.

Based on table above, There are 3 important aspects of soft skills, namely intrapersonal skills, interpersonal skills and social skills. From the 3 aspects, there are 4 indicators, namely self awareness and self skills for intrapersonal skills. Social awareness for interpersonal and leadership for social skill aspects. The indicators are then explained in 20 sub-indicators and then 62 items are prepared. The following are 62 statements in the instrument of soft skills for prospective educators. After going through the expert test (expert judgment) then empirical trials were conducted for prospective users, namely 3rd semester students to obtain data on validity and reliability empirically. The results of the validity and reliability test can be seen in the following table:

Table. 2: Validity of soft skill instruments for educators

\begin{tabular}{|c|l|l|c|}
\hline No & \multicolumn{1}{|c|}{ Subindicator } & Score & Signifikansi \\
\hline 1 & Self Confident & 0.468 & Significant \\
\hline 2 & Self Assessment & 0.415 & Significant \\
\hline 3 & Emotional Awarenes s & 0.388 & Significant \\
\hline 4 & Self Improvement & 0.325 & Significant \\
\hline 5 & Self Contril & 0.371 & Significant \\
\hline 6 & Trust Worthines s & 0.485 & Significant \\
\hline 7 & Time/Resource Management & 0.323 & Significant \\
\hline 8 & Proactif & 0.278 & Significant \\
\hline 9 & Sonscience & 0.660 & Significant \\
\hline 10 & Political Awareness & 0.197 & Significant \\
\hline 11 & Developing Others & 0.537 & Significant \\
\hline 12 & Leveraging Diversity & 0.381 & Significant \\
\hline 13 & Service Orientation & 0.382 & Significant \\
\hline 14 & Empation & 0.400 & Significant \\
\hline 15 & Influence & 0.561 & Significant \\
\hline 16 & Communication Skill & 0.227 & Significant \\
\hline 17 & Conflict Management & 0.314 & Significant \\
\hline 18 & Team Work & 0.409 & Significant \\
\hline 19 & Team Work & 0.625 & 0.579 \\
\hline 20 & Sinergy & & \\
\hline
\end{tabular}

In general it is seen that the instrument used has sufficient validity to be used as a data collection instrument.
Reliability testing also shows that data collection instruments also have high reliability, which is 0.728 . 
Table. 3. Reliability testing

\begin{tabular}{|c|c|}
\hline Cronbach's Alpha & N of Items \\
\hline 728 & 63 \\
\hline
\end{tabular}

It can be concluded that the soft skill instrument of prospective educators fulfills the requirements as a good instrument.
2. Report on mapping the soft skill level of prospective educators

Based on the instruments that have been compiled, further measurements of prospective educator soft skills are carried out for students in 6 faculties at the Jakarta State University, the following results are obtained:

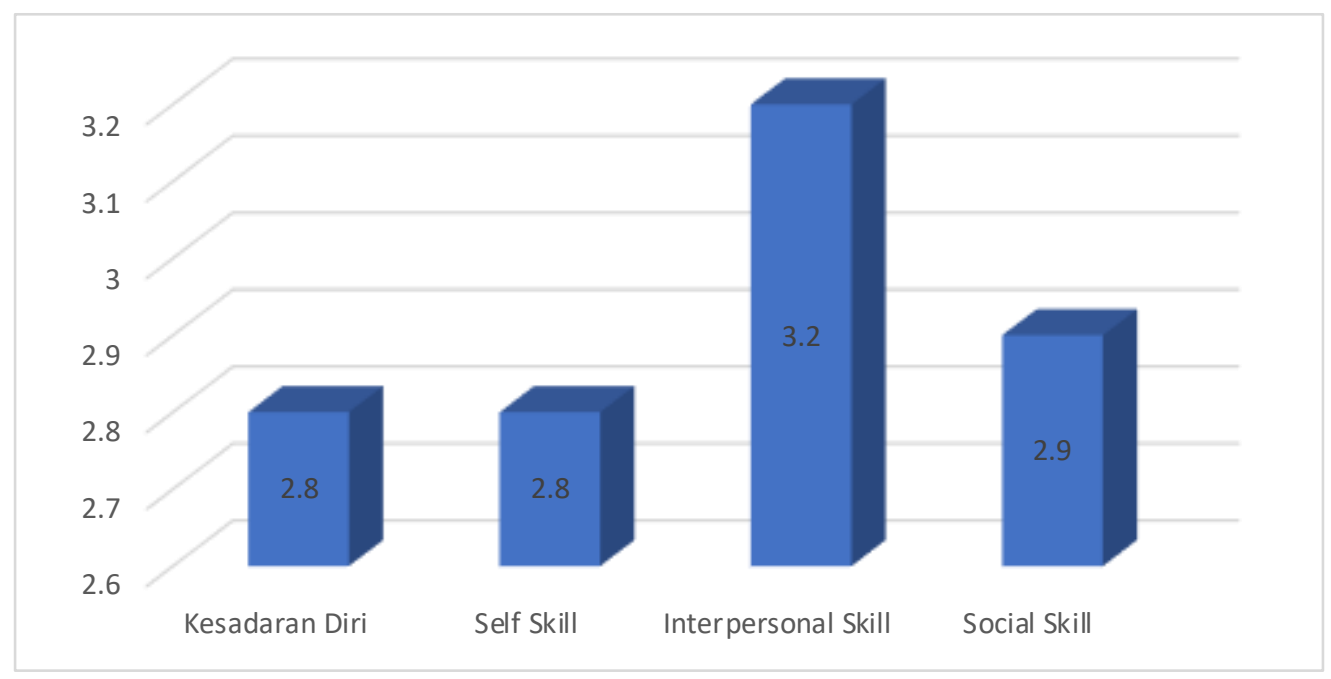

Diagram.1: Soft skill based on indicators

In general, there are numbers that are not too different between the four variables in soft skills, relatively close because they are in the same range of numbers. In the 5th scale the highest mean scores were interpersonal skills, with a mean of 3.2, then social skills (2.9) and self-skills and selfawareness which had the same average score, which was 2.8. It can be concluded that in general soft skills of prospective educators based on 4 main indicators are still not high enough. Based on the measurement results obtained data that in general, soft skills of prospective educators in the FIP are at a moderate level. In line with Schulz's (2008) statement, high soft skills will help educators in carrying out their duties, thus Adam (2013) Sharma \& Sharma (2010) who consider soft skills to be important in education. Thus the moderate level in terms of soft skill will cause the activities of learning activities not to run smoothly, there are some obstacles. Schulz (2008) explains in the communication perspective that soft skills that are not optimal will cause less collegial fluency or with students.

\section{CONCLUSION}

The development of the educator's morning soft skills is very important, because it becomes very important for educators. The ability to manage themselves and the ability to manage students is not only sufficient with pedagogical and methodological skills. The process of developing soft skills that is carried out through various stages, in this case the ongoing activities are the preparation of instruments regarding the types of soft skills that are needed and the development of modules for the development of soft skills. The structured instruments are developed through the stages of instrument preparation, ranging from the development of theoretical constructs, expert tests to empirical tests. While the training module has been developed through the preparation stage to development. At this stage the module is through expert validation, to later be used.

In this study divided into 2 stages because it is multi-year. At this stage, in the first year, the research was carried out by making soft data collection instruments and mapping soft skill levels. This stage is very important because it refers to the research objective, that at this stage there are 2 products that will be produced, namely the soft skills of prospective educators and data regarding the conditions regarding the soft skills of prospective educators.

Based on the research conducted, the following results were obtained:

1. The prospective educator soft skill instrument has a high level of validity and reliability, this conclusion is based on the expert test (expert judgment) and empirical test.

2. Based on the available instruments mapping is done on the soft skills of prospective educators in the Faculty of Education. Measurements were made of 60 FIP students consisting of 6 study programs, namely Guidance and Counseling (BK), Management of Education (MP), Education Curriculum and Technology (KTP), Special Education (PLB), Out of 
School Education (PLS), Education Early Childhood Teacher (PGAUD), Elementary School Teacher Education (PGSD) obtained results that in general the 20 soft skills of prospective educators are at a moderate level with a score of 2.8 to 3.3 on a scale of 5. This means that there is a need for soft skills development through soft skills training prospective educator.

\section{REFERENCES}

[1] Creswell, J.W. (2008). Educational Research Planning, Conduction and Evaluation Quantitative and Qualitative Research. New Jersey: Pearson Educatin. Inc

[2] Adam, C.J (2012). Soft skill'Seen as Key Element for HigherEd. Education Week, 32 (November 14, 2012), 1,14

[3] Atkinson, Rita, Atkinson, Richard, C., \& Hilgard, Ernest, R., 1983. Introduction to psychology, $8^{\text {th }}$ ed. Harcourt Brace Jovanovich, Inc.

[4] Beane, J.A. (1997). Curriculum Integrated: Designing the Core of Democratic Education. New York: Teachers College, Columbia University.

[5] Blanck, JA. (1995). Curriculum Integration and Disipliner of Knowledge. Kappan: Phi Delta

[6] BSNP, (2004). Panduan Pengembangan Kurikulum Tingkat Satuan Pendidikan

[7] Bodell, L (2013). Softskill for the Future, American Society for Training \& Development

[8] Borg, W.R., Gall, J.P., Gall, M.D (2003). Educational Research an Introduction. Boston: Pearson Education, Inc

[9] Chen, Chi-Kuang; Jiang, Bernard C.; and Hsu, KuangYiao. 2005. An Empirical Study of Industrial Engineering and Management Curriculum Reform in Fostering Student's Creativity. European Journal of Engineering Education, Vol. 30, No. 2, 191-202

[10] Davidovitch, Nitza \& Milgram, Roberta M. 2006. Creative Thinking as a Predictor of Teacher Effectiveness in Higher Education. Creativity Research Journal, Vol. 18, No. 3, 385-390

[11] De Freitas S. \& Routledge H. (2013). Designing Leadership and Soft Skills in Educational Games: The E-Leadership and Soft Skills Educational Games Design Model (ELESS). British Journal of Educational Technology Vol. 44 No. 6 (951-968)
[12] Eggen, P., Kauchak, D. Educational Psychology, Third Edition. Prentice Hall. 1997

[13] Erickson. H. Lynn, (2002), Concept Based Curriculum, Teaching Beyond The Fact. Corwin Press. Inc., California

[14] Fogarty, R. (1991). How to Integrate the Curriculum. USA: IRI/Sky Publising Inc.

[15] Friedman, Thomas (2006). The World is Flat, Pinguin Books. England

[16] Gage, N.L. \&Berliner, David, C. (1984). Educational Psychology $3^{r d}$ Ed. Boston, Houghton Mifflin Company

[17] Gagne, Ellen, D., 1985. The Cognitive Psychology of Scholl Learning, Boston, Little, Brown, And Company

[18] Gardner, Howard, (2007). Five Minds for the Future, Gramedia, Jakarta

[19] Jacob, H.H., Ed. (1989). Interdisciplinary Curriculum: Design and Implementation. Alexandria, V.A.: ASCD

[20] Joseph, D. Ang, S, Chang, RH. L. and Slaughter, S.A. (2010). Practical Intelligence in IT: Assessing Sost Skills of IT Professionals. Communications of the Acm Vol. 53 No. 2

[21] Lickona, T (2004). Character Matters. Simon \& Schuster, New York

[22] Schulz, B. 2008. The Importance of Soft Skills: Education beyond Academic Knowledge. NAWA Journal of Language and Communication, 146-153 June 2008

[23] Sharma, G. \& Sharma, P. (2010). Importance of Soft Skills Development in $21^{\text {st }}$ Century Curriculum. International Journal of Education and Allied Sciences. Volume 2 No. 2 pp 39-44

[24] Smith T.H. 2006. Creativity Research Review: Some Lessons for Higher Education. Peer Review. Diakses dari Pro Quest, 3 September 2007

[25] Stenberg, Robert J (Ed) 1999. Handbook of Creativity. Edinburgh: Cambridge University Press

[26] Vygotsky, L.S. (1987). Mind in Society: The Development of Higher Psychological Processes. Massachusset. Harvard University Press

[27] Zhang. A. 2012. Peer Assessment of Soft Skills and Hard Skills. Journal of Information Technology Education .Research Volume 11 